DOI: 10.18276/sip.2017.50/3-13

\author{
Piotr Szczepankowski*
}

University of Finance and Management in Warsaw

\title{
FINANCIALISATION OF THE NON-FINANCIAL CORPORATIONS AND ENTERPRISE VALUE MIGRATION. EVIDENCE FROM THE POLISH STOCK MARKET: 2000-2015
}

\begin{abstract}
One of an approach to financialisation examines the increasing role of the shareholder value orientation as a guiding principle of the non-financial corporations (NFCs) behaviours. Using firm-level data for the period 2000-2015, the article examines the connection between financialisation and enterprise value migration with respect to one of the emerging European capital market which is the Warsaw Stock Exchange. The main purpose of this article is to verify the hypothesis that financialisation affects value migration between two groups of companies - value and growth. The quantitative analysis has used the Generalized Method of Moments (GMM) to measure the relationship between value migration and basic variables for financialisation, which are leverage, financial investment, and financial profits of NFCs. Econometric model revealed a positive relationship between higher financial benefits and value migration. Using a concept of Tobin's Q and its time-changes, it was founded that the increases of firm value driven by financialisation was born most strikingly by increasing financial investment and financial profits, or decreasing corporate leverage. The findings are important to understand links between shareholders value concept and financialisation and they can support managers to prepare effective corporate business policy, which will be expected by shareholders and investors.
\end{abstract}

Keywords: financialisation, non-financial corporation, value migration, shareholder value, capital market

Adres e-mail: szczepankowski@vizja.pl 


\section{Introduction}

In the literature there is no single common definition for financialisation. Most popular was introduced by Esptein (2005), who defines this phenomenon as the growing importance of financial motives, markets, actors and institutions in domestic and international economy. Aalbers (2017) extends this definition and describes financialisation as the increasing dominance of financial measurements, and narratives at various scales, resulting in a structural transformation of economies, firms, states, and households. Dore (2002) asserts that financialisation is the increase of the control of financial industry over total economic activity, the existence of financial controls in company management, inclusion of financial assets in total assets, and the influence of stock markets in company decisions. For Fine (2010), financialisation could be understood as a rise in investment in financial assets along with a decline in accumulation of physical assets. Van der Zwan (2014) identifies three main approaches to the financialisation:

1. Macroeconomic, address the phenomenon on a systemic level,

2. Masoeconomic, base on the concept of shareholder value,

3. Microeconomic, focus on the financialisation of everyday life.

Therefore, financialisation refers to the transformation of the relationships and interactions between financial sector, institutions, markets and non-financial corporations (NFCs) (Karwowski et al., 2016). Financialisation is the occupation of NFCs in the financial markets (Ertürk et al., 2008). Fine (2008) defines financialisation as the NFCs acting like market players in terms of management practices as well. Most of the studies bring forth three important points of financialisation of the NFCs:

- increase financial investment realized by an enterprise,

- large share of profit achieved through financial transactions,

- using a large share of income to pay interests and dividends.

Looking at these points mentioned above, it can be said that the concept of financialisation must have an importance for enterprise market value and its changes. The financialisation of NFCs has led to a restructuring of relations between owners, managers and investors. This phenomenon has had an effect on the stronger position of shareholders. According to that, the growing demand for maximizing shareholder value in the short term has created the conditions for minimizing long-term growth. Financial investment and financial income of NFCs have profound consequences for corporations in terms of investment, growth, and profitability (Fligstein, Shin, 2007; Lin, Tomaskovic-Devey, 2013). These effects are also important for the enterprise 
market value and could strongly influence on capital migration between shareholders' portfolios. Preference towards the maximization of the short term profitability over long term investment points out the changes in corporate activity and business strategy as well.

It was so far not empirically checked an influence of growing financialisation on enterprise market value changes. Given the fact that financialisation of the NFCs is a result of the maximizing shareholder value concept, it should affect on the company market value. In other words, the market value of companies with a higher degree of financialisation should probably grow. As a result, the market value ought to migrate from less to more financialised companies.

Verification of this hypothesis will be made on the basis of one rapidly developing financial market which is the Polish capital market. The dominant focus of researchers on the US and other developed countries markets has introduced bias in the literature. It has encouraged an understanding of financialisation that uses the US experience as the key reference point. Other countries are then evaluated against this experience as more or less financialised (Karwowski et al., 2016). Since Orhangazi (2008) writes that the results of financialisation observed at developed markets would have significant implications for developing countries, changes in financial markets, corporate strategy and governance structures toward the developed countries are on the agenda in many other countries (Glen at al., 2000; Singh, 2003; Soederberg, 2003). Newest researches on financialisation among emerging market economies focuses on changes within a specific country over time (Correa et al., 2012; Ashman, Fine, 2013), systematic comparison across markets (Karwowski, Stockhammer, 2016; Karwowski et al., 2016) or the changing nature of an economic sector (Demir, 2007; 2009). Nevertheless there are not numerous empirical analyses of financialisation of the NFCs from emerging markets.

\section{Financialisation of the NFCs and shareholder value}

Shareholder value concept is most important for understanding the financialisation of NFCs (Williams, 2010). Financialisation reworks the hierarchy of management objectives. Producers must now satisfy not only consumers, but also professional investors, fund managers, and meet the expectations of the capital market. Researchers have attributed financialisation of the NFCs to the emergence of shareholder value as the main principle of corporate behaviour. Shareholder value refers to the idea that 
the primary purpose of corporation is to make profits for the shareholders. According to Aglietta (2000), shareholder value has become the norm of the transformation of capitalism and has provided the justification for the dissemination of new policies and practices favouring shareholders over other stakeholders. Milberg (2008) writes that NFCs became highly financialised organizations and changed business strategies, because most of them despite a downturn in sales growth, increase return to shareholders. Baud and Durand (2012) point out that the developments of financial operations contributed to the NFCs provide high returns to shareholders. They suggest that financialisation refers to the implementation of shareholder value norms, whose consequences are an increase of the financial flows from NFCs to the financial sector, and the increasing share of financial assets owned by the NFCs. Moreover, the shareholder value comes mainly not only from higher rates of return delivered by corporate strategy, but also from rising stock prices (Williams, 2010). Thus, financialisation involves: a) a new competition of financial results with the returns on investment in one firm explicitly compared against all others, regardless of product and sector; b) pressure through the capital market to buy, sell, or hold financial assets; c) a challenge for management which is represented in narrow financial terms; d) the requirement of quick cash returns for shareholders (Froud et al., 2010).

Much of the literature exploring financialisation of the corporate strategies assumes the NFCs to be passive agents that "suffer" the consequences of financial liberalisation, deregulation and globalisation. Numerous studies (Duménil, Lévy, 2004; Stockhammer, 2004; Crotty, 2005; Hein, 2008; Orhangazi, 2008; Dallery, 2009) suggest that financialisation increases the payments made by corporations to financial markets, basically to shareholders (Skott, Ryoo, 2008). Capital accumulation and its combination over time produce also dynamic gains that sustain high levels of financial profitability. Thus, at the firm-level financialisation is a pattern of accumulation in which profits accrue primarily through financial channels rather than through trade and commodity production (Krippner, 2005).

The NFCs increasingly derive profits from financial activities. It suggests that the NFCs have played also an active role in financialising business activities. Available company funds can be invested in financial assets. When the business prospects in financial markets are significantly better than those in goods and services markets, there is a strong incentive for corporations to move investments from tangible to financial assets. Hence, financialisation has generated new profit sources for the NFCs, reinforcing the tendency to underinvestment of gross fixed capital formation (Stockhammer, 2004). 
In shareholder value conception of the firm, corporate efficiency is defined as the ability to maximize dividends and keep stock prices high. Shareholder value has been associated with a particular set of business practices, including the introduction of financial performance measures, such as return on equity, and a short-term business outlook (Widmer, 2011). Lazonick and O'Sullivan (2000) analyzed how financialisation has changed firm management's goals towards maximizing shareholder value in the form of increased dividend payments and share buybacks.

Orhangazi (2008) investigates the effect of financialisation on real investments. He finds a negative relationship between real investment and financialisation. Two channels can help to explain this relationship. Increased financial investment and financial profit opportunities may have crowded out real investment by changing the incentives of firm managers and directing funds away from real investment, and increased payments to the financial markets may have impeded real investment by decreasing available internal funds, shortening the planning horizons of the firm management. Baud and Durand (2012) point additionally out that the preference for liquid assets tends to increase is connected with the fact that a contemporary business environment is characterized by a high level of uncertainty.

The shareholder value motivation, first observed among developed country, has also been increasingly impressed onto emerging market. In the context of the emerging markets, integration in global financial markets and competition with foreign NFCs has put pressure on domestic enterprises to invest in the financial assets, and to generate financial profits. Demir $(2007,2009)$ provided firm-level evidence, and shown that the NFCs in few emerging countries increasingly undertake financial and short-term, often speculative, investment. Farhi and Borghi (2009) argued that international financial integration exposes the NFCs in emerging markets to global competition, pressuring these companies to generate short-term financial profits.

The extreme liquidity of international financial markets offers immense power to institutional investors, who can instantly sell stocks and thus punish corporations that fail to meet the profitability or management criteria established by these markets. Such activities can lead to sudden changes in an enterprise value. The new role that institutional investors have been playing in the management of NFCs has led to profound changes in financial policy. Institutional investors have also imposed new corporate governance criteria, and value measurement. This created a transition from a managerial type of management based on strong internal control of the company to a shareholder model based on external control by financial markets (Aglietta, 2000). Assuming, there are two types of corporate financialisation (Aalbers, 2017): 
1. Of the NFCs, that is, the NFCs becoming dominated by financial narratives, practices, and measurements,

2. Within the NFCs, that is, the NFCs increasingly partaking in practices that have been the domain of the financial sector.

The idea of shareholder value is connecting rather with the first type, and has become dominant in how firms ought to grow and change value.

\section{The value migration concept}

The concept of value migration was introduced by Slywotzky (1996). Based on market value-to-sales ratio (MV/S) he divided companies into three different groups - going through a stage of market value inflow, outflow, and stabilization. These stages describe companies' value-creation power regarding their ability to deal with investors priorities better than the competition and thus to earn superior returns. The main economic factors, determining to which value migration stage a company is included, are: the degree of development measured by total assets, market share measured by sales volume, and profitability.

$\mathrm{MV} / \mathrm{S}$ ratio is not only one possible measure of value migration. Fama and French $(2005,2007)$ described convergence of the price-to-book ratio $(\mathrm{P} / \mathrm{B})$ which determines stock migration between value companies (with low $\mathrm{P} / \mathrm{B}$ ) and growth companies (with high $\mathrm{P} / \mathrm{B}$ ). They studied how stock migration across portfolios contributes to the size and value premiums in average returns. Growth firms tend to be highly profitable and fast growing while value firms are less profitable and grow less rapidly, if they grow at all (Fama, French, 1995). High expected profitability and growth combine with low expected returns produce high $\mathrm{P} / \mathrm{B}$ for the growth stocks, while low profitability, slow growth, and high expected returns produce low $\mathrm{P} / \mathrm{B}$ for the value stocks (Fama, French, 2005). From this perspective, migration denotes movement of value between companies, which takes place owing to shareholders seeking opportunities to invest in effective business models that will create a satisfactory rate of return.

Another possible solution for the study of an enterprise value migration is analyzing time-changes of Q-Tobin coefficient. Tobin's Q is often used in corporate finance studies to measure firm valuation. That coefficient is employed also as a proxy for corporate performance. Otherwise, time-changes of Tobin's Q can explain both 
shareholders and creditors capital migration, so it is appropriate variable of enterprise value migration. In this study Tobin's Q will be calculated from equitation 1:

$$
\mathrm{Q}-\text { Tobin }=\frac{\mathrm{MVE}+\mathrm{A}-\mathrm{BVE}}{\mathrm{A}}
$$

where: $\mathrm{MVE}=$ market value of equity (market capitalization of a company), $\mathrm{A}=$ total assets, $\mathrm{BVE}=$ book value of equity.

Interesting aspect of analysing a value migration is concentrated on answer, which economic results of company activity influence on value changes. Puopolo (2011) and Berk et al. (1999) founded links between market value and investment decisions or changes in assets structure. Companies investing outside their own activity or investing in financial assets introduce a lot of changes to their assets structure which causes the value migration. Pae et al. (2005) hypothesized that earnings conservatism is substantially greater in value firms than in growth ones, and found the negative correlation between earnings conservatism and $\mathrm{P} / \mathrm{B}$ ratio. Beaver and Ryan (2004) observed that earnings are negatively correlated with Tobin's Q. The existing relevant literature suggests that Tobin's $Q$ also depends on growth opportunities in the future, which are associated with real investment projects (Feltham, Ohlson, 1996) and individual assets structure as well as debt structure of a company (Beaver, Ryan, 2004). Richardson et al. (2006) showed that changes in Tobin's Q have a strong positive correlation with sales growth. Cohen and Lys (2006) found that Tobin's Q has a strong negative correlation with leverage. Hardouvelis et al. (2012) investigated the relationship between changes in Tobin's Q and the anomaly on corporate financing activities. Naccur and Goained (1997) positively verified a hypothesis that payment of dividends and a company's profitability exert a significant influence on $\mathrm{P} / \mathrm{B}$ ratio and Tobin's $\mathrm{Q}$.

Some of the empirical analyses were carried out in order to study the relationship between P/B or Tobin's Q and the selected value indicators. O'Byrne (1996) determined that economic value added (EVA ${ }^{\mathrm{TM}}$ ) explains near one third of Tobin's $\mathrm{Q}$ while a annual change in EVA ${ }^{\mathrm{TM}}$ - over half of annual change in Tobin's Q. Finegan (1990) demonstrated that return on invested capital (ROIC) may account for almost half of annual change in Tobin's Q. Whereas Dodd and Chen (1996) claim that ROA explains almost quarter of Tobin's $\mathrm{Q}$ while the other profitability ratios are insignificant. In contrast, Telaranta (1997) proved that all profitability ratios explain Tobin's $Q$ to a little extent. Hall (2002) demonstrated that none of different financial variables significantly explain the changes of Tobin's Q. 
Although we have to remember that $\mathrm{P} / \mathrm{B}$ or Tobin's $\mathrm{Q}$ have gained much credence as an indicator of value-growth orientation, it is by no means an ideal measure (Chan, Lakonishok, 2004). Both of them are not a clean variables uniquely associated with economically interpretable characteristics of a firm as many different factors are reflected in these ratios.

\section{Financialisation and value migration: results of an empirical analysis and discussion}

In this section I specify a value migration model that can account for the potential effects of financialisation while controlling for other determinants of value migration delineated in the previous section.

In order to study the dependencies between value migration and financialisation, I decided to carry out analysis of panel data. The sample consists 230 non-financial companies listed on the Warsaw Stock Exchange (WSE) during the period 2000 to 2015. The sample is an unbalanced panel, as a firm is not required to have observations for all years in the period. I do not use a sample of balanced panel data in the analysis in order to avoid surveillance bias. Financial data were obtained from companies annual reports, and market capitalization of the companies was obtained from the WSE.

The dependent variable in the study is the firm market value changes. I use Tobin's $\mathrm{Q}$ annual changes $(\Delta \mathrm{Q})$ as a proxy of value migration. Tobin's $\mathrm{Q}$ of company $i$ at time $t$ was calculated from equitation 1.

The independent variables, which can be used as the key indicators of the NFCs' financialisation are:

- the share of financial assets in total assets (FIN_A),

- financial profits to total earnings (FIN_P),

- long-term debt to total assets (LEVERAGE),

- financialisation index, which is the average of all the above-mentioned ratios (FINANC_INX).

Besides financialisation parameters there are several other economic variables which can influence on the value migration. The empirical studies shown that timechanges of Tobin's $Q$ are significant depended on four main proxies: size of company, investment activity, assets efficiency, and firm profitability. Those parameters are additionally introduced to regression models as the control (non-financialisation) 
variables. The size of company (SIZE) is calculated as the natural logarithm of total assets. Investment activity (INV_RATE) is measured by capital expenditures divided by total assets. Assets efficiency is measured by total assets turnover ratio (A_TURN), which is the relation between net sales and total assets. The profitable is understood here as a return on invested capital (ROIC) and is measured by earning before interests and taxes divided by total assets. Table 1 presents descriptive statistics for the variables used in the study.

Table 1. Descriptive Statistics

\begin{tabular}{|l|c|c|c|}
\hline \multicolumn{1}{|c|}{ Variable } & Mean & Std. Dev. & Median \\
\hline Tobin's Q & 1.5730 & 0.9327 & 1.3023 \\
\hline FIN_A & 0.0790 & 0.0925 & 0.0448 \\
\hline FIN_P & 0.0095 & 0.0008 & 0.0082 \\
\hline LEVERAGE & 0.4295 & 0.1983 & 0.4552 \\
\hline SIZE & 13.2897 & 2.1075 & 13.3636 \\
\hline INV_RATE & 0.1764 & 0.1583 & 0.1294 \\
\hline A_TURN & 1.1450 & 0.0983 & 1.2052 \\
\hline ROIC & 0.0953 & 0.0147 & 0.0887 \\
\hline
\end{tabular}

Source: own calculation.

In the table 2 the correlation matrix is presented. There are no high correlations between independent variables, which could lead to multicolineality problems and, consequently, inconsistent estimations.

Table 2. Correlation Matrix

\begin{tabular}{|l|cccccccc|}
\hline & Tobin's Q & FIN_A & FIN_P & LEVERAGE & SIZE & INV_RATE & A_TURN & ROIC \\
\hline Tobin's Q & 1.0000 & & & & & & & \\
FIN_A & $0.2923^{* * *}$ & 1.0000 & & & & & & \\
FIN_P & 0.0216 & $0.8724^{*}$ & 1.0000 & & & & & \\
LEVERAGE & $-0.0530^{* * *}$ & $0.6050^{* * *}$ & -0.0060 & 1.0000 & & & & \\
SIZE & $0.0814^{* *}$ & $0.1694^{* *}$ & $0.0093^{*}$ & $0.0821^{* * *}$ & 1.0000 & & & \\
INV_RATE & $0.1569^{* *}$ & $0.1238^{*}$ & $0.0116^{*}$ & $0.1214^{* * *}$ & $0.1054^{* * *}$ & 1.0000 & & \\
A_TURN & $0.2134^{* *}$ & 0.2187 & $0.0012^{*}$ & $0.0387^{* *}$ & $0.0894^{* * *}$ & $0.2112^{*}$ & 1.0000 & \\
ROIC & $0.2678^{* *}$ & $0.0067^{* *}$ & $0.1123^{* *}$ & $0.0745^{* * *}$ & $0.0153^{* *}$ & $0.0761^{* *}$ & $0.2287^{*}$ & 1.0000 \\
\hline
\end{tabular}

*significant at $10 \% ; *$ significant at $5 \% ; * * *$ significant at $1 \%$ level 
At the end of each year three portfolios based on Tobin's Q were formed. These were portfolios of growth firms ( $40 \%$ of companies, with high Tobin's Q), neutral ( $20 \%$ of companies, with average Tobin's Q), and value firms ( $40 \%$ of companies, with low Tobin's Q). At the end of next year, changes in the portfolio structure were observed. As a result of the observation, I split each portfolio into three migration groups:

1. Same - firms that stay in the same portfolio,

2. Plus - firms that improve in type, that is, they move toward growth companies from previous neutral (Same) and value (Minus) portfolios,

3. Minus - firms that deteriorate, that is, they move toward value companies from growth (Plus) and neutral (Same) portfolios.

Next, I examined factors determining only Plus and Minus value migration. I did not pursue evaluation of the factors implicating non-migration or firms remained in Same portfolio.

A significant degree of heterogeneity among the firms might generate outliers, which can bias the empirical results. Corporate data usually have large outliers, especially when the variables are expressed in the form of ratios. According to Chirinko et al. (1999), I apply a two-step procedure to eliminate outliers. In the first step, I calculate firm means for each regression variable. Second, I exclude the firms whose means fall in the $1 \%$ or the $99 \%$ tail of distribution of the variable in the sample.

On the basis of the available data, panel model has been developed assuming the firm-fixed effects. In order to eliminate autocorrelation of the random variable, I have finally decided to use a dynamic panel data model. The dynamic of value migration model was estimated using the Arellano-Bond Generalized Method of Moments (GMM). The GMM method of estimation controls for unobservable heterogeneity and prevents potential endogeneity problems. To eliminate unobservable firm-fixed effects, variables are first differenced and year dummies are used to account for unobservable time-specific factors. The GMM method consists in, among others, replacing the original values of independent variables with the values of instrumental variables non-correlated with the random variable in the model. Conventionally, estimation of parameters takes place along with verification of autocorrelation of the random variable (Arellano, Bond, 1991) and examination of endogeneity with the Sargan test. Adoption of this method of estimation leads to elimination of the absolute term and the individual effects in the first stage of the procedure (hence the relevant parameters are not provided in the table containing the results of estimation). The estimated model takes form presented by equitation 2 . 


$$
\Delta \mathrm{Q}_{\mathrm{it}}=\delta \cdot \Delta \mathrm{Q}_{\mathrm{i}, \mathrm{t}-1}+\sum_{\mathrm{j}} \beta_{\mathrm{j}} \cdot \Delta \mathrm{X}_{\mathrm{jit}}+\alpha \cdot \Delta \mathrm{XFIN}_{\mathrm{it}}+\Delta \varepsilon_{\mathrm{it}}
$$

where: $\Delta \mathrm{Q}_{\mathrm{it}}=$ annual change of Tobin's $\mathrm{Q}$ in year $\mathrm{t}$ for corporate $\mathrm{i} ; \Delta \mathrm{Q}_{\mathrm{i}, \mathrm{t}-1}=$ annual change of Tobin's $\mathrm{Q}$ in previous year; $\Delta \mathrm{X}_{\mathrm{jit}}=$ annual change of the $\mathrm{j}$ independent non-financialisation variable (control variable) in year $\mathrm{t}$ for corporate $\mathrm{i} ; \Delta \mathrm{XFIN}_{\mathrm{it}}=$ annual change of financialisation indicators for corporate $\mathrm{i}$ in year $\mathrm{t} ; \Delta \varepsilon_{\mathrm{it}}=$ annual change of IID random variable.

The results of diagnostic tests are presented in Table 3.

Table 3. Financialisation of the NFCs and enterprise value migration

\begin{tabular}{|l|l|l|l|l|l|l|c|c|}
\hline \multirow{2}{*}{\multicolumn{1}{c}{ Variable }} & \multicolumn{5}{|c|}{ Plus value migration } & \multicolumn{5}{c|}{ Minus value migration } \\
\cline { 2 - 10 } & Model 1 & Model 2 & Model 3 & Model 4 & Model 5 & Model 6 & Model 7 & Model 8 \\
\hline Q-Tobin (t-1) & 0.020 & 0.064 & 0.029 & $0.021^{* * *}$ & -0.031 & -0.058 & 0.046 & -0.012 \\
\hline SIZE & 0.201 & 0.112 & $0.503^{* *}$ & 0.453 & 0.147 & 0.391 & -0.075 & 0.550 \\
\hline INV_RATE & 0.116 & 0.178 & 0.091 & 0.083 & -0.102 & -0.143 & -0.399 & -0.261 \\
\hline A_TURN & 0.112 & 0.530 & 0.641 & 1.274 & 0.062 & 0.072 & 0.026 & 0.010 \\
\hline ROIC & 0.257 & 0.158 & 0.964 & 0.830 & -0.017 & -0.042 & -0.041 & -0.130 \\
\hline FIN_A & $4.320^{* * *}$ & & & & $-0.606^{* *}$ & & & \\
\hline FIN_P & & $0.023^{*}$ & & & & $-6.370^{* * *}$ & & \\
\hline LEVERAGE & & & $-0.025^{*}$ & & & & $0.031^{* * * *}$ & \\
\hline FINANC_INX & & & & $17.830^{* * *}$ & & & & $-9.901^{* * *}$ \\
\hline N of obs. & 1390 & 1390 & 1390 & 1390 & 1370 & 1370 & 1370 & 1370 \\
\hline p-values: & & & & & & & & \\
Sargan test & 0.653 & 0.584 & 0.528 & 0.784 & 0.602 & 0.645 & 0.598 & 0.711 \\
AR1 of error & 0.209 & 0.221 & 0.310 & 0.334 & 0.218 & 0.236 & 0.324 & 0.350 \\
AR2 of error & 0.351 & 0.435 & 0.966 & 0.621 & 0.387 & 0.336 & 0.846 & 0.655 \\
\hline
\end{tabular}

*significant at $10 \%$; * significant at $5 \% ; * * *$ significant at $1 \%$ level

Source: own calculation.

I start the discussion by examining whether the control (non-financialisation) variables used in the model are appropriate for explaining value migration. In general, the control variables have mostly the expected signs in both Plus and Minus value migration models, but almost all specifications have not statistical significance. Only in two models of Plus migration, level of annual changes of Tobin's Q in previous period (model 4) and SIZE (model 3) have statistical significance. It has to be concluded that the assets of larger NFCs from the sample are valuated with market premium and their market value tends to run over a longer period. On emerging markets capital has often flowed to larger than to smaller NFCs. 
The parameters expressing the influence of three single financialisation indicators have strong statistical significant in each models. For both Plus and Minus migration, coefficients of the basic financialisation indicators have the expected signs. When the sample is divided into Plus and Minus migration, the signs remain changed. FIN_A and FIN_P confirm the positive correlation between financialisation and Plus, but negative for Minus value migration. LEVERAGE is negatively correlated with Plus and positively with Minus value migration. Moreover, the conclusion on the positive (negative) correlation between the Plus (Minus) value migration and FINANC_INX may be drawn with greatest confidence level. Thus, increasing level of financialisation increases the enterprise market value, and decreasing level of financialisation decreases market value, what is connected with the investors' expectations. According to the financialisation and maximizing shareholder value concepts, investors move capital from the enterprises with low level of the financialisation to ones more financialised, because they expect higher returns in the short period.

It also shows that the financialisation indicators used in research are appropriate measures of assessment of this phenomenon. Growing share of financial assets, and increasing financial returns well describe the impact of financialisation on the enterprise value changes. The results of research support also the hypothesis that increased financial assets can change enterprise market value by focusing managerial investment decisions on projects making return expected by shareholders in relatively short periods. Orhangazi (2008) named it as shortening the planning horizons of the NFCs. Statistical findings presented here support also the argument that increased investment in financial assets increase enterprise market value by either directing investors' capital away from real sector of economy and saving it on financial markets or by shortening the managerial planning horizon as firms are either trying to meet short-term return expectations of the financial markets or as the managers are trying to realize value based management theory by increasing the short-term value of the firm and hence maximize their personal benefits.

The financial profit variable employed in the regression models provides interesting results. Minus value migration is more sensitive to the financial profit than Plus one. Annual changes in the financial profit influence stronger on market value decreasing than increasing or are statistically more significant for value than for growth companies. Moreover, a coefficient on the financial profit variable would be consistent with financial assets or liquidity-based investment theory and with the financing constraint hypothesis. Financial market investors are expecting that income from financial assets should be used to finance future long-term investment policy 
of company. It has important meaning for market value changes and value migration as well. This is also consistent with the argument that increased financial profit reflects a change in the managerial preferences towards short-termism and financial investment.

The last used financialisation indicator was the long-term debt-to-assets ratio (LEVERAGE). It has a negative and statistically significant coefficient for Plus and positive for Minus value migration. This indicates that higher leverage constrain value migration as it increases the financial uncertainty of the firms and increases the financial and investment risk. An interesting note is perhaps that the annual changes of the leverage ratio have a smaller impact on value migration than other financialisation indicators. In general, the statistical results show that as the long-term indebtedness of the NFCs increases it may have a negative effect on market value and direction of the value migration.

To sum up, I find strong evidence that financialisation has effects on the firm market value and value migration between value and growth companies. Increasing financialisation of the NFCs improves value migration from value to growth companies, and decreasing financialisation causes value migration from growth to value ones.

\section{Concluding remarks}

The paper analyzed the potential effects of financialisation on the enterprise value migration. Financialisation of the NFCs has two aspects. On the one side, the NFCs increase their financial assets and hence derive an increasing part of their profits from financial sources. On the other side, the NFCs are under increased pressure from the shareholders and financial markets to increase returns in short time. These two aspects of financialisation could have effects on enterprise value migration between different groups of the NFCs - value and growth companies.

Increased financial assets of the NFCs can reduce real investment and economic growth of the firm, but financial investment can also increased financial profit, which can change the enterprise market value and investors' decisions. Therefore, the developed hypothesis was that high financial profit opportunities lead to higher financial assets of the NFCs and result in a growth of enterprise value and its migration. Moreover, the financial profits increased total firm earnings what can cause increasing shareholders demand for receive higher payouts. 
Furthermore, the increasing shares of financial assets in total assets of the NFCs require additional external invested capital obtained from creditors. The firms with higher level of financial assets have also higher level of leverage. Such a situation causes dependence of companies on the financial institutions and increases uncertainty. This factor causes the value outflow of this group of companies to the enterprises with less indebtedness.

The model was tested by using firm-level data. The findings indicate a relationship between financialisation and enterprise value migration - positive for value inflow and negative for value outflow. The results support the view that financialisation has positive implications for firms' market value growth. Although the results presented are not necessarily conclusive, because they represent results only from one capital market, and they represent a new attempt to examine the relationship between financialisation and enterprise value migration. The findings indicate that, overall, the nature of relationship between contemporary financial markets and the NFCs are a complex problem and might create impediments, especially for longterm economic growth. So, the arguments and findings of this paper have relevance for the debates about changes in financial systems, economic growth and enterprise value on emerging capital markets.

\section{References}

Aalbers, M.B. (2017). Corporate financialization. In: Richardson, D et al. (eds.), The international encyclopedia of geography: people, the earth, environment, and technology. Oxford: Wiley.

Aglietta, M. (2000). Shareholder value and corporate governance. Some tricky questions. Economy and Society, 29, 146-159.

Arrelano, M., Bond, S. (1991). Some tests of specification for panel data. Monte Carlo evidence and an application to employment equations. Review of Economic Studies, 58, 277-297.

Ashman, S., Fine, B. (2013). Neo-liberalism, varieties of capitalism, and the shifting contours of South Africa's financial system. Transformation: Critical Perspectives on Southern Africa, 81 (1), 144-178.

Baud, C., Durand, C. (2012). Financialization, globalization and the making of profits by leading retailers. Socio-Economic Review, 10, 241-266.

Beaver, W., Ryan, S. (2004). Conditional and unconditional conservatism: concepts and modeling. Working Paper. Review of Accounting Studies Conference. 
Berk, J.B., Green, R.C., Naik, V. (1999). Optimal investment, growth options and security returns. Journal of Finance, 54, 1153-1607.

Chan, L., Lakonishok, J. (2004). Value and growth investing: Review and update. Financial Analysts Journal, 60 (1), 71-86.

Chirinko, R.S., Fazzari, A., Meyer, C. (1999). How responsive is business capital formation to its user cost? An exploration with macro data. Journal of Public Economics, 74, 53-80.

Cohen, D., Lys, T. (2006). Weighing the evidence on the relation between external corporate financing activities, accruals and stock returns. Journal of Accounting and Economics, 42, 87-105.

Correa, E., Vidal, G., Marshall, W. (2012). Financialization in Mexico: trajectory and limits. Journal of Post Keynesian Economics, 35 (2), 255-275.

Crotty, J. (2005). The neoliberal paradox: the impact of destructive product market competition and modern financial markets on nonfinancial corporation performance in the neoliberal era. W: G.A. Epstein (ed.), Financialization and the World Economy 77-110. Northampton: Edward Elgar Publishing.

Dallery, T. (2009). Post-Keynesian theories and the firm under financialization. Review of Radical Political Economics, 41, 492-515.

Demir, F. (2007). The rise of rentier capitalism and the financialization of real sectors in developing countries. Review of Radical Political Economics, 39 (3), 351-359.

Demir, F. (2009). Financial liberalization, private investment and portfolio choice: financialization of real sectors in emerging markets. Journal of Development Economics, 88 (2), 314-324.

Dodd, J.L., Chen, S. (1996). EVA: a new panacea. Business and Economic Review, 42, 26-38.

Dore, R. (2002). Stock market capitalism and its diffusion. New Political Economy, 7 (1), $115-121$.

Duménil, G., Lévy, D. (2004). The real and financial components of profitability (USA 1952-2000). Review of Radical Political Economics, 36 (1), 82-110.

Epstein, G. (ed.) (2005). Financialization and the world economy. London: Edward Elgar.

Ertürk, I., Froud, J., Johal, S., Leaver, A., Williams, K. (2008). Financialization at work: key texts and commentary. London \& New York: Routledge.

Fama, E.F., French, K.R. (1995). Size and book-to-market factors in earnings and returns. Journal of Finance, 50, 131-155.

Fama, E.F., French, K.R. (2005). The anatomy of value and growth returns. University of Chicago Working Paper.

Fama, E.F., French, K.R. (2007). Migration. Financial Analysts Journal, 63 (3), 48-58.

Farhi, M., Borghi, R.A.Z. (2009). Operations with financial derivatives of corporations from emerging economies. Estudos Avançados, 23, 169-188.

Feltham, G., Ohlson, J. (1996). Uncertainty resolution and the theory of depreciation measurement. Journal of Accounting Research, 34 (2), 209-234. 
Fine, B. (2008). From financialization to neo-liberalism: engaging neo-liberalism. School of Oriental and African Studies Working Papers, London: University of London.

Fine, B. (2010). Locating financialization. Historical Materialism, 18 (2), 97-116.

Finegan, P.T. (1990). Maximizing shareholder value at the private company. Journal of Applied Corporate Finance, 1, 15-25.

Fligstein, N., Shin, T. (2007). Shareholder value and the transformation of the US economy: 1984-2000. Sociological Forum, 22, 399-424.

Froud, J., Haslam, C., Johal, S., Williams, K. (2010). Shareholders value and financialization: consultancy promises, management moves. Economy and Society, 29 (1), 80-110.

Glen, J., Lee, K., Singh, A. (2000). Competition, corporate governance and financing of corporate growth in emerging markets. Cambridge Discussion Paper in Accounting and Finance AF46, Department of Applied Economics, University of Cambridge.

Hall, J.H. (2002). Dissecting EVA: the value drivers determining the shareholder value of industrial company. Department of Financial Management, University of Pretoria. http://papers.ssrn.com/abstract=304196. Accessed 15 Feb 2010.

Hardouvelis, G., Papanastasopoulos, G., Thomakos, D., Wang, T. (2012). External financing, growth and stock returns. European Financial Management, 18 (5), 790-815.

Hein, E. (2008). Financialization in a comparative static, stock-flow consistent post-Kaleckian distribution and growth model. IMK Working Paper 21. Hans Boeckler Foudation, Macroeconomic Policy Institute.

Karwowski, E., Stockhammer, E. (2016). Financialization in emerging economies: a systematic overview and comparison with Anglo-Saxon economies. Working Paper 1616, Post Keynesian Economics Study Group.

Karwowski, E., Shabani, M., Stockhammer, E (2016). Financialization: dimensions and determinants. A cross-country study. Working Paper 1619, Post Keynesian Economics Study Group.

Krippner, G. (2005). The financialization of the American economy. Socio-Economic Review, 3 (2), 173-208.

Lazonick, W., O’Sullivan, M. (2000). Maximizing shareholder value. A new ideology for corporate governance. Economy and Society, 29 (1), 13-35.

Lin, K.H., Tomaskovic-Devey, D. (2013). Financialization and US income inequality, 19702008. American Journal of Sociology, 118, 1284-1329.

Milberg, W. (2008). Shifting sources and uses of profits: sustaining US financialization with global value chains. Economy and Society, 37 (3), 420-451.

Naccur, S.B., Goaied, M. (1997). The value creation process in the Tunisian stock exchange. Working Paper API/WPS 9903, University of Tunisia.

O’Byrne, S.F. (1996). EVA and market value. Journal of Applied Corporate Finance, 9 (1), 34-40.

Orhangazi, O. (2008). Financialization and capital accumulation in the non-financial corporate sector. A theoretical and empirical investigation on the US economy: 1973-2003. Cambridge Journal of Economics, 32, 863-886. 
Pae, J., Thornton, D.B., Welker, M. (2005). The link between earnings conservatism and the price-to-book ratio. Contemporary Accounting Research, 22 (3), 693-717.

Puopolo, G.W. (2011). The dynamics of Tobin's $Q$. http://ssrn.com/abstract=2022569. Accessed 15 Feb 2010.

Richardson, S., Sloan, R., Soliman, M., Tuna, I. (2006). The implications of firm growth and accounting distortions for accruals and profitability. The Accounting Review, 81, $713-743$.

Singh, A. (2003). Competition, corporate governance and selection in emerging markets. Economic Journal, 113, 443-464.

Slywotzky, A.J. (1996). Value migration. How to think several moves ahead of the competition. Boston: Harvard Business School Press.

Skott, P., Ryoo, S. (2008). Macroeconomic implication of financialization. Cambridge Journal of Economics, 32, 827-862.

Soederberg, S. (2003). The promotion of "Anglo-American" corporate governance in the South: who benefits from the new international standard. Third World Quarterly, 27 (1), 7-27.

Stockhammer, E. (2004). Financialization and the slowdown of accumulation. Cambridge Journal of Economics, 28 (5), 719-741.

Telaranta, T. (1997). On residual income variables and shareholder wealth creation. Helsinki School of Economics and Business Administration, http://evanomics.com/evastudy/ evastudy.shtml. Accessed 10 Sept 2000.

Van der Zwan, N. (2014), Making sense of financialization. Socio-Economic Review, 12, 99-129.

Widmer, F. (2011). Institutional investors, corporate elites and the building of a market for corporate control. Socio-Economic Review, 9, 671-697.

Williams, K. (2010). From shareholder value to present-day capitalism. Economy and Society, 20 (1), 1-12.

\section{FINANSYZACJA PRZEDSIĘBIORSTW A MIGRACJA ICH WARTOŚCI NA PRZYKŁADZIE SPÓŁEK GIEŁDOWYCH W POLSCE ZA LATA 2000-2015}

\section{Streszczenie}

Jedno z podejść do opisu zjawiska finansyzacji koncentruje uwagę na analizie oddziaływania koncepcji zarządzania wartością na zmiany zachowań (decyzji) finansowych przedsiębiorstw. Artykuł odnosi się do tej problematyki. Wykorzystując dane finansowe spółek niefinansowych notowanych na Giełdzie Papierów Wartościowych w Warszawie w latach 2000-2015, przedstawiono w nim wyniki badania zależności pomiędzy stopniem finansyzacji jednostki gospodarczej i migracją jej wartości rynkowej. Głównym celem opra- 
cowania jest weryfikacja hipotezy o istotnym wpływie finansyzacji na kierunek i siłę migracji wartości pomiędzy dwiema grupami przedsiębiorstw, tj. spółkami wartościowymi i wzrostowymi. Badanie zostało oparte na analizie zależności między miernikiem migracji wartości i wybranymi wskaźnikami finansyzacji przedsiębiorstw niefinansowych, jakimi są: stopień zadłużenia aktywów, udział aktywów finansowych w zasobach majątkowych oraz udział zysku z działalności finansowej w dochodach całkowitych. Do oceny natężenia i kierunku migracji wartości wykorzystano roczne zmiany wielkości wskaźnika Q-Tobina. Otrzymane wyniki wskazują, że na wzrost wartości rynkowej spółek pozytywnie wpływa wzrost inwestycji w aktywa finansowe oraz wysokość zysków osiąganych z działalności finansowej. Negatywny wpływ ma zaś stopa zadłużenia aktywów. Przeprowadzona obserwacja empiryczna pozwala lepiej zrozumieć współzależność między koncepcją zarządzania wartością i zjawiskiem finansyzacji, co może okazać się przydatne dla zarządzających przedsiębiorstwami przy formułowaniu akceptowanych przez właścicieli oraz inwestorów strategii wzrostu i rozwoju jednostek gospodarczych.

Słowa kluczowe: finansyzacja, przedsiębiorstwo niefinansowe, migracja wartości, wartość dla akcjonariuszy, rynek kapitałowy 